\title{
Moderately high frequency ventilation with a conventional ventilator allows reduction of tidal volume without increasing mean airway pressure
}

\author{
Ricardo Luiz Cordioli ${ }^{1,2,46^{*}}$, Marcelo Park ${ }^{1,3}$, Eduardo Leite Vieira Costa ${ }^{1,2}$, Susimeire Gomes ${ }^{2}$, Laurent Brochard ${ }^{5}$, \\ Marcelo Britto Passos Amato ${ }^{2}$ and Luciano Cesar Pontes Azevedo ${ }^{1,3}$
}

\author{
* Correspondence: \\ ricardocordioli@uol.com.br \\ ${ }^{1}$ Research and Education Institute, \\ Hospital Sírio-Libanês, Rua Dona \\ Adma Jafet, 91, Bela Vista, São Paulo \\ 01308-050, Brazil \\ ${ }^{2}$ Laboratório de Investigação \\ Médica 09, Heart Institute (InCor), \\ Hospital das Clínicas da Faculdade \\ de Medicina da Universidade de \\ São Paulo, Av. Rebouças, 381-Jardim \\ Paulista, São Paulo, São Paulo \\ 05401-000, Brazil \\ Full list of author information is \\ available at the end of the article
}

\begin{abstract}
Background: The aim of this study was to explore if positive-pressure ventilation delivered by a conventional ICU ventilator at a moderately high frequency (HFPPV) allows a safe reduction of tidal volume $\left(V_{T}\right)$ below $6 \mathrm{~mL} / \mathrm{kg}$ in a porcine model of severe acute respiratory distress syndrome (ARDS) and at a lower mean airway pressure than high-frequency oscillatory ventilation (HFOV).

Methods: This is a prospective study. In eight pigs (median weight 34 [29,36] kg), ARDS was induced by pulmonary lavage and injurious ventilation. The animals were ventilated with a randomized sequence of respiratory rates: 30, 60, 90, 120, 150, followed by HFOV at $5 \mathrm{~Hz}$. At each step, $V_{\mathrm{T}}$ was adjusted to allow partial pressure of arterial carbon dioxide $\left(\mathrm{PaCO}_{2}\right)$ to stabilize between 57 and $63 \mathrm{mmHg}$. Data are shown as median [P25th,P75th]

Results: After lung injury, the $\mathrm{PaO}_{2} / \mathrm{FiO}_{2}$ (P/F) ratio was $92[63,118] \mathrm{mmHg}$, pulmonary shunt $26[17,31] \%$, and static compliance $11[8,14] \mathrm{mL} / \mathrm{cmH}_{2} \mathrm{O}$. Positive end-expiratory pressure (PEEP) was $14[10,17] \mathrm{cmH}_{2} \mathrm{O}$. At 30 breaths/min, $V_{T}$ was higher than $6(7.5$ $[6.8,10.2]) \mathrm{mL} / \mathrm{kg}$, but at all higher frequencies, $V_{T}$ could be reduced and $\mathrm{PaCO}_{2}$ maintained, leading to reductions in plateau pressures and driving pressures. For frequencies of 60 to $150 / \mathrm{min}, V_{T}$ progressively fell from $5.2[5.1,5.9]$ to $3.8[3.7,4.2] \mathrm{mL} / \mathrm{kg}$ $(p<0.001)$. There were no detrimental effects in terms of lung mechanics, auto-PEEP generation, hemodynamics, or gas exchange. Mean airway pressure was maintained constant and was increased only during HFOV.

Conclusions: During protective mechanical ventilation, HFPPV delivered by a conventional ventilator in a severe ARDS swine model safely allows further tidal volume reductions. This strategy also allowed decreasing airway pressures while maintaining stable $\mathrm{PaCO}_{2}$ levels.

Keywords: Mechanical ventilation; Acute lung injury; Critical care unit; Protective ventilation; Acute respiratory distress syndrome; High-frequency ventilation
\end{abstract}

\section{Springer}

\section{Background}

Acute respiratory distress syndrome (ARDS) is a common cause of mortality and morbidity in critically ill patients [1]. Although indispensable in the support of ARDS patients, artificial ventilation involves the application of mechanical forces to the lung parenchyma that can further induce injury [2], adding morbidity and mortality [3]. 
Reducing tidal volumes $\left(V_{\mathrm{T}} \mathrm{s}\right)$ below $6 \mathrm{~mL} / \mathrm{kg}$ of ideal body weight could potentially decrease the cyclic stretch imposed on the lung $[4,5]$. Conversely, excessively low $V_{\mathrm{T}}$ s have the potential to lead to clinically significant hypercapnia-related acidosis [6] with harmful side effects $[7,8]$.

In this scenario, high-frequency oscillatory ventilation (HFOV) has been tested, because of its ability to provide adequate gas exchange even at very low tidal volumes [9-13]. This technique, however, may be cumbersome because it requires a dedicated ventilator and special training. Additionally, the $V_{\mathrm{T}}$ delivered can be susceptible to variations in airway resistance such as that which occurs with lung secretions [14]. Last but not least, it requires the use of high airway pressures, which may have deleterious effects, especially on the right ventricle [15]. Recently, two clinical studies in ARDS patients showed neutral [16] or disappointing [17] results in terms of mortality when HFOV was compared to a conventional mechanical ventilation strategy.

An alternative approach could be to apply moderately high frequency positive-pressure ventilation (HFPPV) using conventional mechanical ventilators. A similar strategy was explored in the 1980s [18,19], but with special ventilators and before the well-established recognition of the importance of lung-protective strategies. HFPPV consists of applying respiratory rates intermediate between those used conventionally ( $\leq 35$ breaths $/ \mathrm{min}$ ) and those used during HFOV (180 to 800 breaths/min). Potential advantages over HFOV would be the possibility to control the $V_{\mathrm{T}}$ delivered, the use of conventional mechanical ventilators obviating the need for specialized training, and maintenance of a low mean airway pressure. In this feasibility study, we tested in a swine model of ARDS whether such a strategy could result in $V_{\mathrm{T}}$ below $6 \mathrm{~mL} / \mathrm{kg}$ while avoiding further increases in the partial pressure of arterial carbon dioxide $\left(\mathrm{PaCO}_{2}\right)$ and maintaining a reasonable mean airway pressure $\left(P_{\text {mean }}\right)$.

\section{Methods}

This study was approved by the Institutional Animal Research Ethics Committees of Hospital Sírio Libanês and of Faculdade de Medicina da Universidade de São Paulo, both in São Paulo, Brazil, and was performed according to the National Institutes of Health (USA) guidelines for the use of experimental animals. The experiments were done in eight previously healthy Agroceres pigs.

\section{Instrumentation}

The animals were fasted overnight before the experiment with free access to water. They received an intramuscular injection of midazolam $\left(0.3 \mathrm{mg} / \mathrm{kg}\right.$; Dormonid ${ }^{\circ}$, Roche, São Paulo, Brazil) and acepromazine $\left(0.5 \mathrm{mg} / \mathrm{kg}\right.$; Acepran ${ }^{\circ}$, Andrômaco, São Paulo, Brazil). Through an auricular vein, anesthesia was induced with thionembutal (12 mg/ kg; Tiopental ${ }^{\circ}$, Abbott, São Paulo, Brazil) and muscular relaxation with pancuronium bromide $\left(0.1 \mathrm{mg} / \mathrm{kg}\right.$; Pavulon ${ }^{\circ}$ AKZO Nobel, São Paulo, Brazil). They were then submitted to tracheal intubation (cuffed 7.5-French cannula) and connected to the Servo300 mechanical ventilator (Maquet, Rastatt, Germany) with the following parameters in a volume-controlled mode: tidal volume of 8 to $10 \mathrm{~mL} / \mathrm{kg}$, positive end-expiratory pressure (PEEP) of $5 \mathrm{cmH}_{2} \mathrm{O}$, inspiratory fraction of oxygen $\left(\mathrm{FiO}_{2}\right)$ adjusted to keep arterial saturation between $94 \%$ and $96 \%$, and respiratory rate (RR) necessary to keep $\mathrm{PaCO}_{2}$ between 35 and $45 \mathrm{mmHg}$. Anesthesia was maintained during the study period with midazolam $(0.3 \mathrm{mg} / \mathrm{kg} / \mathrm{h})$ and fentanyl citrate $\left(5 \mu \mathrm{g} / \mathrm{kg} / \mathrm{h}\right.$; Fentanyl ${ }^{\circ}$, Janssen-Cilag, São 
Paulo, Brazil) and muscular relaxation with pancuronium bromide $(0.2 \mathrm{mg} / \mathrm{kg} / \mathrm{h})$. The adequate depth of anesthesia during the surgical period was evaluated with maintenance of physiological variables (heart rate and arterial pressure) and absence of reflexes (corneal and hind limb flexion response), as well as unresponsiveness to stimuli during manipulation. Supplementary boluses of 3 to $5 \mu \mathrm{g} / \mathrm{kg}$ of fentanyl and 0.1 to $0.5 \mathrm{mg} / \mathrm{kg}$ of midazolam were administered as necessary. A continuous drip of 1,000 mL/h of Lactated Ringer's solution was infused until the end of the induction of pulmonary injury, and then a continuous infusion of $5 \mathrm{~mL} / \mathrm{kg} / \mathrm{h}$ of Lactated Ringer was maintained until the end of the study.

Monitoring with continuous electrocardiography, oxymetry, and blood pressures was done with a multiparametric monitor (Dixtal-Philips DX 2020, São Paulo, Brazil). The left femoral artery was cannulated for blood pressure monitoring and blood sampling. The right internal jugular vein was cannulated with a 9-French introducer sheath (Arrow, Reading, PA, USA) through which a pulmonary artery catheter (Edwards Lifesciences, Irvine, CA, USA) was introduced for monitoring of the mean pulmonary artery pressure (PAPm), cardiac output, central venous pressure (CVP), and mixed venous blood gases $\left(\mathrm{SvO}_{2}\right)$. A central venous catheter was introduced in the left internal jugular vein. A surgical cystostomy was done to quantify the urine output. The animal was connected to the $\mathrm{NICO}_{2}$ device (Novametrix Medical Systems, Wallingford, CT, USA) for airway end-tidal pressure of carbon dioxide $\left(\mathrm{EtCO}_{2}\right)$, tidal volume, airway pressures, and airway flow monitoring.

The regional ventilation was monitored with electrical impedance tomography (EIT; Dixtal-Philips, São Paulo, Brazil) [20,21]. The lungs were split in sternal and vertebral regions of the same height. The amount of ventilation to the regions studied was reported according to the ventilator settings used. Arterial blood gas analyses were done with the ABL 800 device (Radiometer, Copenhagen, Denmark). After the surgical period, the animals were allowed to rest for 60 min prior to the baseline data acquisition.

\section{Measurements}

In all the steps of the study, the following data were collected:

1. Hemodynamic: heart rate, cardiac output, CVP, mean systemic arterial blood pressure (ABPm), PAPm, pulmonary artery occlusion pressure (PAOP), $\mathrm{SvO}_{2}$, and norepinephrine use and dosage

2. Respiratory: arterial partial pressure of oxygen $\left(\mathrm{PaO}_{2}\right), \mathrm{PaCO}_{2}, \mathrm{EtCO}_{2}, V_{\mathrm{T}}$, airway peak pressure $\left(P_{\text {peak }}\right)$, airway plateau pressure $\left(P_{\text {plateau }}\right)$ through expiratory valve occlusion after $2 \mathrm{~s}$ of inspiratory pause, intrinsic positive end-expiratory pressure (PEEPi) through expiratory valve occlusion after $4 \mathrm{~s}$ of expiratory pause, extrinsic positive end-expiratory pressure (PEEPe), mean airway pressure $\left(P_{\text {mean }}\right)$, inspiratory flow, inspiratory time $\left(T_{\text {insp }}\right)$, and ventilatory distribution EIT data

3. Metabolic: $\mathrm{pH}$, lactate, temperature, and fluid balance

\section{Calculated variables}

To obtain the calculated variables, we used the following formulas:

- Cardiac index $(\mathrm{CI})=$ Cardiac output/Weight

- Systemic vascular resistance index $=(\mathrm{ABPm}-\mathrm{CVP}) \times 80 / \mathrm{CI}$ 
- Pulmonary vascular resistance index $=(\mathrm{PAPm}-\mathrm{PAOP}) \times 80 / \mathrm{CI}$

- Blood oxygen content $\left(\mathrm{C} \times \mathrm{O}_{2}\right)=\mathrm{P} \times \mathrm{O}_{2} \times 0.0031+1.36 \times \mathrm{Hb} \times \mathrm{S} \times \mathrm{O}_{2}$

- Minute ventilation $=V_{\mathrm{T}} \times \mathrm{RR}$

- PEEPtotal $=$ PEEPi + PEEPe

- Alveolar oxygen partial pressure $\left(\mathrm{P}_{\mathrm{A}} \mathrm{O}_{2}\right)=643 \times \mathrm{FiO}_{2} / 100-\left(\mathrm{PaCO}_{2} / 0.8\right)$

- Alveolar-arterial oxygen $\left[(\mathrm{A}-\mathrm{a}) \mathrm{O}_{2}\right.$ ] gradient $=\mathrm{P}_{\mathrm{A}} \mathrm{O}_{2}-\mathrm{PaO}_{2}$

- Pulmonary capillary oxygen content $\left(\mathrm{CcO}_{2}\right)=\mathrm{PAO}_{2} \times 0.0031+1.36 \times \mathrm{Hb}$

- Pulmonary shunt $=\left(\mathrm{CcO}_{2}-\mathrm{CaO}_{2}\right) \times 100 /\left(\mathrm{CcO}_{2}-\mathrm{CvO}_{2}\right)$

- Static compliance $\left(C_{\text {static }}\right)=V_{\mathrm{T}} /\left(P_{\text {plateau }}-\right.$ PEEPtotal $)$

- Dynamic compliance $\left(C_{\mathrm{dyn}}\right)=V_{\mathrm{T}} /\left(P_{\text {peak }}-\right.$ PEEPtotal $)$

- Resistance $\left(P_{\text {peak }}-P_{\text {plateau }}\right) /$ Inspiratory flow

\section{ARDS induction}

After the baseline data collection, ARDS was induced with repeated whole-lung lavage using $1 \mathrm{~L}$ of isotonic saline $\left(37^{\circ} \mathrm{C}\right)$ until the $\mathrm{PaO}_{2}$ was below $100 \mathrm{mmHg}$ for at least $10 \mathrm{~min}$. Lung injurious ventilation was then started with the animal ventilated in pressure control mode with $\mathrm{PEEP}=3 \mathrm{cmH}_{2} \mathrm{O}, \mathrm{FiO}_{2}=1$, inspiratory/expiratory time ratio $(\mathrm{I} / \mathrm{E})=1: 1, P_{\text {peak }}=42 \mathrm{cmH}_{2} \mathrm{O}$, and a $\mathrm{RR}$ of 20 to 30 breaths $/ \mathrm{min}$ [22]. Arterial blood gases were obtained every $15 \mathrm{~min}$, and the PEEP could be increased up to $19 \mathrm{cmH}_{2} \mathrm{O}$ targeting a $\mathrm{PaO}_{2}$ level between 55 and $80 \mathrm{mmHg}$, whereas the inspiratory pressure was limited at $48 \mathrm{cmH}_{2} \mathrm{O}$. The injurious ventilation was maintained until one of the following parameters was reached:

- An interval of 240 min of injurious ventilation

- A PAPm $>50 \mathrm{mmHg}$

- A $C_{\text {static }}<10 \mathrm{~mL} / \mathrm{cmH}_{2} \mathrm{O}$ (with a PEEP $=10 \mathrm{cmH}_{2} \mathrm{O}$ and $V_{\mathrm{T}}=6 \mathrm{~mL} / \mathrm{kg}$ )

- A PEEP persistently $\geq 15 \mathrm{cmH}_{2} \mathrm{O}$ for at least two consecutive arterial blood sample analyses

- An $\mathrm{ABPm}<70 \mathrm{mmHg}$ in spite of the use of norepinephrine in a dosage higher than $0.5 \mu \mathrm{g} / \mathrm{kg} / \mathrm{min}$

After lung injury induction, the stabilization step started. The animal was ventilated according to the recommendations of the interventional group in the "ARMA" study [5] in a volume-controlled mode, with $V_{\mathrm{T}}=6 \mathrm{~mL} / \mathrm{kg}, \mathrm{RR}=35$ breaths $/ \mathrm{min}$ (the maximal respiratory rate allowed by the protocol - because of hypercapnia and acidosis), initial $\mathrm{PEEP}=10 \mathrm{cmH}_{2} \mathrm{O}$ (mean value used in the ARMA study), and $\mathrm{FiO}_{2}=1$.

An arterial blood sample was obtained every $10 \mathrm{~min}$. Subsequently, PEEP and $\mathrm{FiO}_{2}$ were titrated according to the ARMA study PEEP table (aiming at a $\mathrm{PaO}_{2}=55$ to $80 \mathrm{mmHg}$ ) [5]. $V_{\mathrm{T}}$ and RR were kept constant during the stabilization step with no attempt to correct the $\mathrm{PaCO}_{2}$ level.

\section{Experimental protocol}

After reaching a $\mathrm{PaCO}_{2}$ equilibrium (variation $<5 \%$ in three consecutive arterial blood samples), we considered that the stabilization phase was finished. The same PEEP level titrated at this time was used in the following steps of the study. 
Four sequences of five different RRs were randomly tested, and these sequences were chosen to alternate higher and lower respiratory frequencies (Figure 1). The five RRs (ventilatory modes) randomized were as follows: $\mathrm{RR}=30,60,90,120,150$ breaths $/ \mathrm{min}$. At each sequence, $V_{\mathrm{T}}$ was adjusted to reach a $\mathrm{PaCO}_{2}$ target of 57 to $63 \mathrm{mmHg}$.

The randomization was done using sealed envelopes containing the proportion of 1:1:1:1 of the following RR sequences:

- Sequence $1(60,150,90,120,30)$

- Sequence $2(90,30,120,60,150)$

- Sequence $3(120,150,90,30,60)$

- Sequence $4(150,90,30,120,60)$

During this part of the protocol, the animals were ventilated using volume control ventilation, with $\mathrm{FiO}_{2}=1$ and square inspiratory flow $=1 \mathrm{~L} / \mathrm{s}$. At each step, PEEPi was measured every $10 \mathrm{~min}$, and PEEPe was corrected in order to keep the PEEPtotal equal to the PEEP obtained during the equilibrium step using the ARMA PEEP table.

After completion of these randomized sequences, the animals were submitted to HFOV (Figure 1) at $5 \mathrm{~Hz}$ (SensorMedics 3100B, Yorba Linda, CA, USA) with a $P_{\text {mean }}$ set at $30 \mathrm{cmH}_{2} \mathrm{O}, \mathrm{I} / \mathrm{E}=1: 2$, bias flow $=30 \mathrm{~L} / \mathrm{min}$, and the initial pressure amplitude $=80$ $\mathrm{cmH}_{2} \mathrm{O}$ [9]. Unlike the other five RRs, of which the sequence was randomized, HFOV was always performed last, because of its higher $P_{\text {mean }}$, which could induce lung recruitment.

An arterial blood sample was obtained each 10 min throughout the remainder of the study. After $V_{\mathrm{T}}$ changes or after pressure amplitude changes during HFOV, we waited until there were three consecutive measurements with the $\mathrm{PaCO}_{2}$ levels stable between 57 and $63 \mathrm{mmHg}$. Data were then collected, and the next step of the sequence was started. Between consecutive steps, a 40-s disconnection from the ventilator was done in order to avoid the carryover of the time-dependent alveolar recruitment. At the end of the experiments, the anesthesia was deepened with propofol overdose, and the animals were euthanized with a bolus of $10 \mathrm{~mL}$ of potassium chloride $19.1 \%$.

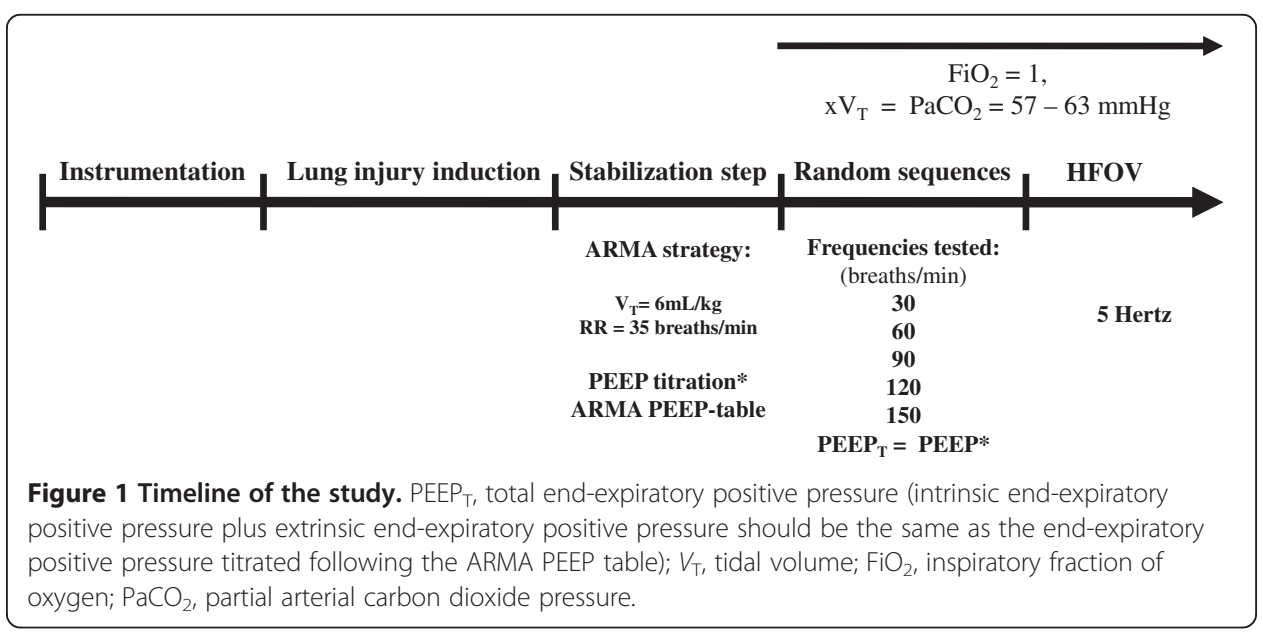




\section{Statistical analysis}

The Shapiro-Wilk goodness-of-fit model showed a non-parametrical distribution for most variables; therefore, data are reported as median [P25th,P75th]. Wilcoxon's signed rank test was used to test variables before and after lung injury induction and to compare the upper and lower regional ventilation with the EIT. In order to avoid type I error, a modified Bonferroni's correction was used to account for the multiple comparisons between upper and lower regions of ventilation. Therefore, the $p$ value considered significant was 0.007 when comparing upper and lower regions during the various frequencies studied and 0.012 when comparing the effects of inspiratory pauses and the alveolar recruitment with a RR of 60 breaths $/ \mathrm{min}$. The analysis of variance for repeated measures on ranks (Friedman's test) was used for analyses during the ventilatory modes tested. The post hoc analyses were done using Student-Newman-Keuls' test. A $p<0.05$ was considered significant. The analyses and graphs were done with the SigmaPlot 12.0 statistical package software (Systat Software, Inc. San Jose, CA, USA).

\section{Results}

Eight pigs weighing $34[29,39] \mathrm{kg}$ were used. ARDS was induced using $10[7,16] \mathrm{L}$ of normal saline followed by injurious mechanical ventilation for 210 [40,225] min. The respiratory variables at baseline and after the induction of lung injury are shown in Table 1.

The $\mathrm{FIO}_{2}$ during the stabilization step was $0.7[0.5,0.9]$. The time to $\mathrm{PaCO}_{2}$ equilibrium was similar in the different phases of the experiment and equal to $50[40,75] \mathrm{min}$. The most important respiratory data with different RRs are shown in Figure 2 and Table 2. During the stabilization step, $\mathrm{PaCO}_{2}$ was $81[78,92] \mathrm{mmHg}$. In all other experimental phases, the $\mathrm{PaCO}_{2}$ was kept in the planned range of 57 to $63 \mathrm{mmHg}$ (Figure 2A). $V_{\mathrm{T}}$ could be progressively reduced with increasing RRs (Figure 2B), as did regional ventilation (Figure 3 ). The ventilation to the dependent parts of the lung reduced to a greater extent leading to an increase in the sternal/vertebral ratio of regional ventilation (Figure 4). Additionally, low values of plateau and driving pressures were maintained at all RRs (Figure 2C,D, respectively). The HFOV led to the highest oxygenation, the lowest $V_{\mathrm{T}}$, and the most homogeneous distribution of ventilation (Table 2, Figures $2 \mathrm{~B}$ and 4 , respectively).

Only one animal needed norepinephrine during HFPPV, and the dose varied between $2.4 \mu \mathrm{g} / \mathrm{kg} / \mathrm{min}(\mathrm{HFPPV}=60)$ and $3.2 \mu \mathrm{g} / \mathrm{kg} / \mathrm{min}(\mathrm{HFOV})$. The hemodynamic and metabolic data with different RRs are shown in Table 3. Of note, the stabilization step with

Table 1 Respiratory variables at baseline and after the induction of lung injury

\begin{tabular}{lcc}
\hline Variable & Baseline & After lung injury \\
\hline P/F ratio $(\mathrm{mmHg})$ & $427[368,473]$ & $97[67,130]^{*}$ \\
Shunt $(\%)$ & $13[12,15]$ & $23[16,32]^{*}$ \\
Tidal volume (sternal) & $4.8[3.7,5.9]$ & $4[4.5,3.5]$ \\
Tidal volume $($ ventral) & $4.2[3.0,5.4]$ & $2.5[2,3]$ \\
$C_{\text {static }}\left(\mathrm{mL} / \mathrm{CmH}_{2} \mathrm{O}\right)$ & $27[15,30]$ & $12[9,14]$ \\
Resistance $\left(\mathrm{cmH}_{2} \mathrm{O} / \mathrm{L} / \mathrm{s}\right)$ & $8[7,10]$ & $18[14,26]^{*}$ \\
\hline
\end{tabular}

Values are presented as median [P25th,P75th] $C_{\text {static }}$ and P/F denote static compliance and the ratio of arterial oxygen concentration to the fraction of inspired oxygen, respectively. ${ }^{*} p<0.05$ vs baseline, Wilcoxon's signed rank test. 


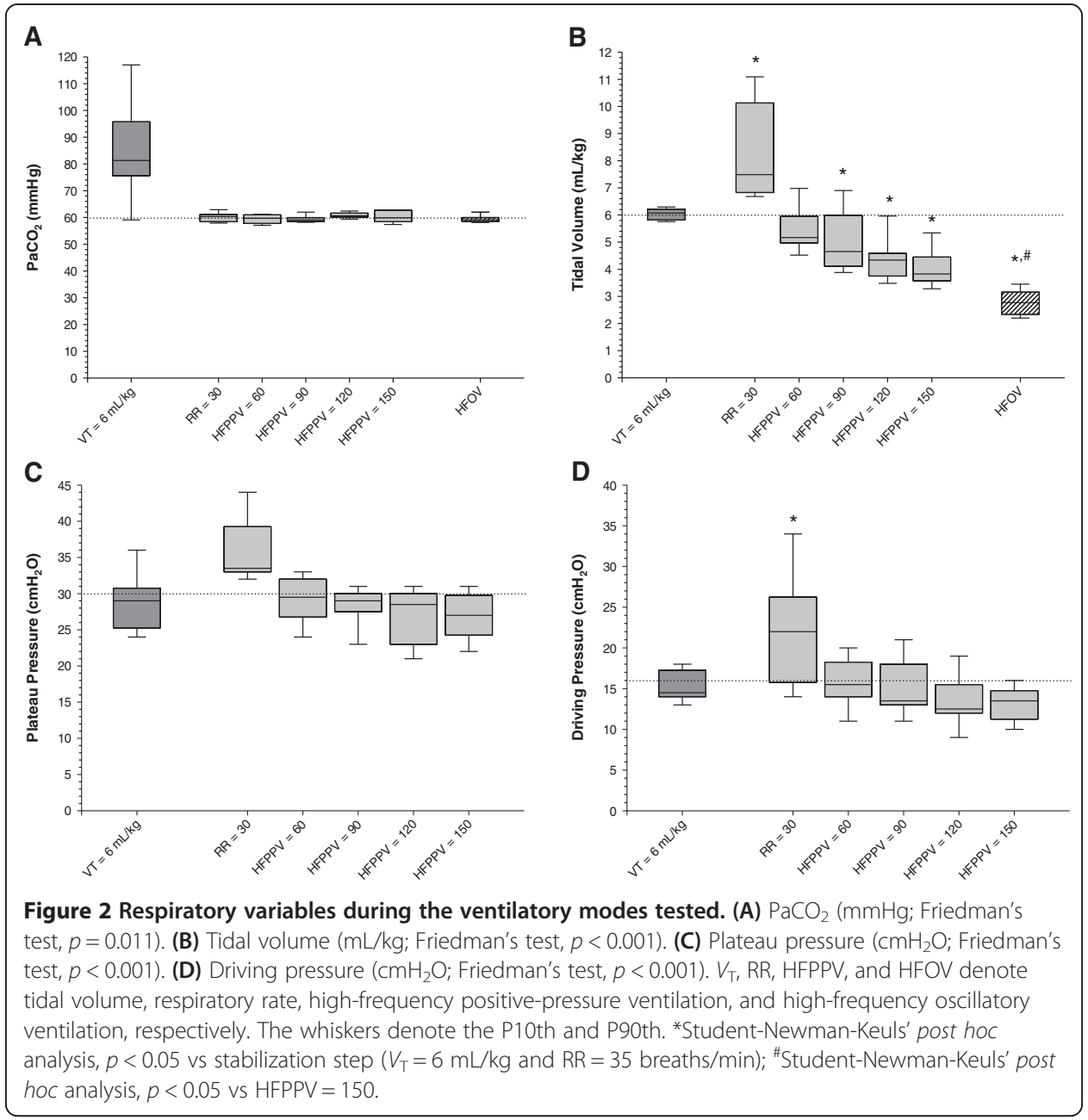

$V_{\mathrm{T}}=6 \mathrm{~mL} / \mathrm{kg}$ and $\mathrm{RR}=35$ breaths $/ \mathrm{min}$ was associated with higher pulmonary artery pressures and lower $\mathrm{pH}$.

\section{Discussion}

Our main finding was that, during protective mechanical ventilation of a severe ARDS swine model, the use of HFPPV with a conventional ventilator allows further reductions in $V_{\mathrm{T}}$ and $\mathrm{PaCO}_{2}$, leading to reductions in driving pressures and plateau pressures without increasing mean airway pressure. We did not identify any significant detrimental effect of the high RRs applied, even after careful assessment of hemodynamics, respiratory system mechanics, and gas exchange.

The possibility of further reducing the ventilator-associated lung injury is of utmost importance, with possible implications in terms of reducing death and multiple organ failure in ARDS patients [23]. Ventilation with low $V_{\mathrm{T}} \mathrm{S}(6 \mathrm{~mL} / \mathrm{kg})$ is still the standard support for those patients [5], although lower $V_{\mathrm{T}} \mathrm{s}$ might produce additional protection $[6,24]$. Of note, one third of ARDS patients under protective ventilation still have lung hyperdistention, which is associated with increases in systemic inflammatory markers [25]. This subset of patients, usually more severely injured, could possibly benefit from further $V_{\mathrm{T}}$ reductions [24]. 
Table 2 Respiratory variables through the ventilatory modes tested

\begin{tabular}{|c|c|c|c|c|c|c|c|c|}
\hline Variable & $\begin{array}{c}V_{\mathrm{T}}= \\
6 \mathrm{~mL} / \mathrm{kg}\end{array}$ & $\begin{array}{c}\mathrm{RR}= \\
30\end{array}$ & $\begin{array}{c}\text { HFPPV }= \\
60\end{array}$ & $\begin{array}{c}\text { HFPPV }= \\
90\end{array}$ & $\begin{array}{c}\text { HFPPV }= \\
120\end{array}$ & $\begin{array}{c}\text { HFPPV }= \\
150\end{array}$ & HFOV & $\begin{array}{c}p \\
\text { value }^{\text {a }}\end{array}$ \\
\hline $\begin{array}{l}\text { P/F ratio } \\
(\mathrm{mmHg})\end{array}$ & $\begin{array}{c}95 \\
{[87,105]}\end{array}$ & $\begin{array}{c}151 \\
{[117,181]^{b}}\end{array}$ & $\begin{array}{c}141 \\
{[102,189]^{b}}\end{array}$ & $\begin{array}{c}132 \\
{[95,169]^{b}}\end{array}$ & $\begin{array}{c}111 \\
{[86,162]^{b}}\end{array}$ & $\begin{array}{c}112 \\
{[90,171]^{b}}\end{array}$ & $\begin{array}{c}193 \\
{[146,216]^{b, c}}\end{array}$ & $\begin{array}{c}P= \\
0.003\end{array}$ \\
\hline $\begin{array}{l}\text { Gradient } \\
(\mathrm{A}-\mathrm{a}) \mathrm{O}_{2}\end{array}$ & $\begin{array}{c}480 \\
{[465,493]}\end{array}$ & $\begin{array}{c}396 \\
{[383,452]^{\mathrm{b}}}\end{array}$ & $\begin{array}{c}427 \\
{[378,468]^{\mathrm{b}}}\end{array}$ & $\begin{array}{c}427 \\
{[394,466]}\end{array}$ & $\begin{array}{c}455 \\
{[406,481]}\end{array}$ & $\begin{array}{c}458 \\
{[394,478]}\end{array}$ & $\begin{array}{c}365 \\
{[350,420]^{b, c}}\end{array}$ & $\begin{array}{c}P= \\
0.014\end{array}$ \\
\hline $\begin{array}{l}\text { Minute } \\
\text { ventilation } \\
\text { (L/min) }\end{array}$ & $\begin{array}{c}6.9 \\
{[6.6,8.8]}\end{array}$ & $\begin{array}{c}8.7 \\
{[7.4,10.0]}\end{array}$ & $\begin{array}{c}11.1 \\
{[11.0,11.5]^{b}}\end{array}$ & $\begin{array}{c}15.6 \\
{[14.0,17.5]^{b}}\end{array}$ & $\begin{array}{c}18.6 \\
{[13.0,19.2]^{b}}\end{array}$ & $\begin{array}{c}20.2 \\
{[19.5,21.3]^{b}}\end{array}$ & $\begin{array}{c}27 \\
{[23.5,28.4]^{b, c}}\end{array}$ & $\begin{array}{c}P< \\
0.001\end{array}$ \\
\hline Shunt (\%) & $\begin{array}{c}43 \\
{[41,45]}\end{array}$ & $\begin{array}{c}29 \\
{[26,34]^{\mathrm{b}}}\end{array}$ & $\begin{array}{c}34 \\
{[30,40]}\end{array}$ & $\begin{array}{c}31 \\
{[28,44]}\end{array}$ & $\begin{array}{c}34 \\
{[31,45]}\end{array}$ & $\begin{array}{c}38 \\
{[30,43]}\end{array}$ & $\begin{array}{c}27 \\
{[25,32]^{b, c}}\end{array}$ & $\begin{array}{c}P= \\
0.003\end{array}$ \\
\hline $\begin{array}{l}\mathrm{EtCO}_{2} \\
(\mathrm{mmHg})\end{array}$ & $\begin{array}{c}58 \\
{[52,60]}\end{array}$ & $\begin{array}{c}43 \\
{[32,47]^{b}}\end{array}$ & $\begin{array}{c}41 \\
{[37,49]^{b}}\end{array}$ & $\begin{array}{c}40 \\
{[30,45]^{b}}\end{array}$ & $\begin{array}{c}40 \\
{[31,48]^{b}}\end{array}$ & $\begin{array}{c}34 \\
{[28,36]^{\mathrm{b}}}\end{array}$ & $\begin{array}{c}27 \\
{[23,30]^{\mathrm{b}, c}}\end{array}$ & $\begin{array}{c}P< \\
0.001\end{array}$ \\
\hline $\begin{array}{l}C_{\text {static }}(\mathrm{mL} / \\
\left.\mathrm{CmH}_{2} \mathrm{O}\right)\end{array}$ & $\begin{array}{c}12 \\
{[10,14]}\end{array}$ & $\begin{array}{c}12 \\
{[9,14]}\end{array}$ & $\begin{array}{c}10 \\
{[9,13]}\end{array}$ & $\begin{array}{c}10 \\
{[9,12]^{\mathrm{b}}}\end{array}$ & $\begin{array}{c}10 \\
{[7,11]^{\mathrm{b}}}\end{array}$ & $\begin{array}{c}9 \\
{[8,11]^{\mathrm{b}}}\end{array}$ & - & $\begin{array}{c}P= \\
0.001\end{array}$ \\
\hline $\begin{array}{l}\mathrm{C}_{\mathrm{dyn}}(\mathrm{mL} / \\
\left.\mathrm{cmH}_{2} \mathrm{O}\right)\end{array}$ & $\begin{array}{c}8 \\
{[7,9]}\end{array}$ & $\begin{array}{c}9 \\
{[6,10]}\end{array}$ & $\begin{array}{c}7 \\
{[6,9]}\end{array}$ & $\begin{array}{c}7 \\
{[6,8]}\end{array}$ & $\begin{array}{c}6 \\
{[5,7]^{b}}\end{array}$ & $\begin{array}{c}6 \\
{[5,7]^{\mathrm{b}}}\end{array}$ & - & $\begin{array}{c}P< \\
0.001\end{array}$ \\
\hline $\begin{array}{l}\text { Resistance } \\
\left(\mathrm{cmH}_{2} \mathrm{O} / \mathrm{L} / \mathrm{s}\right)\end{array}$ & $\begin{array}{c}8 \\
{[8,10]}\end{array}$ & $\begin{array}{c}10 \\
{[9,12]^{\mathrm{b}}}\end{array}$ & $\begin{array}{c}9 \\
{[8,9]^{b}}\end{array}$ & $\begin{array}{c}9 \\
{[8,9]^{b}}\end{array}$ & $\begin{array}{c}8 \\
{[8,11]^{b}}\end{array}$ & $\begin{array}{c}9 \\
{[8,13]^{b}}\end{array}$ & $\begin{array}{c}17 \\
{[13,20]^{\mathrm{b}, c}}\end{array}$ & $\begin{array}{c}P< \\
0.001\end{array}$ \\
\hline $\begin{array}{l}\text { PEEP total } \\
\left(\mathrm{cmH}_{2} \mathrm{O}\right)\end{array}$ & $\begin{array}{c}14 \\
{[11,17]}\end{array}$ & $\begin{array}{c}14 \\
{[10,17]}\end{array}$ & $\begin{array}{c}14 \\
{[10,17]}\end{array}$ & $\begin{array}{c}13 \\
{[10,16]}\end{array}$ & $\begin{array}{c}13 \\
{[10,17]}\end{array}$ & $\begin{array}{c}13 \\
{[10,17]}\end{array}$ & - & $\begin{array}{c}P= \\
0.744\end{array}$ \\
\hline $\begin{array}{l}\text { PEEP intrinsic } \\
\left(\mathrm{CmH}_{2} \mathrm{O}\right)\end{array}$ & 0 & 0 & 0 & $\begin{array}{c}0 \\
{[0,1]}\end{array}$ & $\begin{array}{c}0 \\
{[0,1]}\end{array}$ & $\begin{array}{c}2 \\
{[1,3]^{b}}\end{array}$ & - & $\begin{array}{c}P< \\
0.001\end{array}$ \\
\hline $\begin{array}{l}\text { PEEP extrinsic } \\
\left(\mathrm{CmH}_{2} \mathrm{O}\right)\end{array}$ & $\begin{array}{c}14 \\
{[11,16]}\end{array}$ & $\begin{array}{c}14 \\
{[11,16]}\end{array}$ & $\begin{array}{c}13 \\
{[10,17]}\end{array}$ & $\begin{array}{c}13 \\
{[10,16]}\end{array}$ & $\begin{array}{c}13 \\
{[10,16]}\end{array}$ & $\begin{array}{c}12 \\
{[9,14]}\end{array}$ & - & $\begin{array}{c}P< \\
0.001\end{array}$ \\
\hline $\begin{array}{l}\text { Peak pressure } \\
\left(\mathrm{CmH}_{2} \mathrm{O}\right)\end{array}$ & $\begin{array}{c}45 \\
{[44,48]}\end{array}$ & $\begin{array}{c}54 \\
{[47,58]^{\mathrm{b}}}\end{array}$ & $\begin{array}{c}44 \\
{[42,47]}\end{array}$ & $\begin{array}{c}44 \\
{[41,45]}\end{array}$ & $\begin{array}{c}41 \\
{[38,44]}\end{array}$ & $\begin{array}{c}41 \\
{[38,43]}\end{array}$ & $\begin{array}{c}59 \\
{[51,79]^{\mathrm{b}, c}}\end{array}$ & $\begin{array}{c}P< \\
0.001\end{array}$ \\
\hline $\begin{array}{l}P_{\text {mean }} \\
\left(\mathrm{cmH}_{2} \mathrm{O}\right)\end{array}$ & $\begin{array}{c}17 \\
{[15,20]}\end{array}$ & $\begin{array}{c}18 \\
{[16,22]^{\mathrm{b}}}\end{array}$ & $\begin{array}{c}18 \\
{[15,22]^{b}}\end{array}$ & $\begin{array}{c}20 \\
{[18,23]^{b}}\end{array}$ & $\begin{array}{c}20 \\
{[18,24]^{b}}\end{array}$ & $\begin{array}{c}20 \\
{[17,23]^{\mathrm{b}}}\end{array}$ & $\begin{array}{c}29 \\
{[28,30]^{\mathrm{b}, c}}\end{array}$ & $\begin{array}{c}P< \\
0.001\end{array}$ \\
\hline $\begin{array}{l}\text { Inspiratory } \\
\text { flow }(L / s)\end{array}$ & 1 & 1 & 1 & 1 & 1 & 1 & - & $\begin{array}{c}P= \\
1.000\end{array}$ \\
\hline$T_{\text {insp }} / T_{\text {tot }}(\%)$ & $\begin{array}{c}15 \\
{[14,17]}\end{array}$ & $\begin{array}{c}19 \\
{[14,22]}\end{array}$ & $\begin{array}{c}24 \\
{[20,28]^{b}}\end{array}$ & $\begin{array}{c}34 \\
{[30,37]^{b}}\end{array}$ & $\begin{array}{c}38 \\
{[33,44]^{b}}\end{array}$ & $\begin{array}{c}42 \\
{[37,49]^{b}}\end{array}$ & $\begin{array}{c}56 \\
{[50,67]^{\mathrm{b}, c}}\end{array}$ & $\begin{array}{c}P< \\
0.001\end{array}$ \\
\hline
\end{tabular}

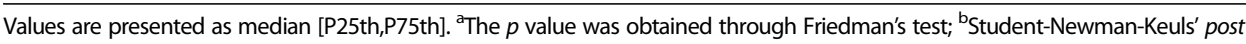
hoc analysis, $p<0.05$ vs $V_{T}=$ stabilization step $\left(V_{T}=6 \mathrm{~mL} / \mathrm{kg}\right.$ and $\left.\mathrm{RR}=35 \mathrm{breaths} / \mathrm{min}\right)$; 'Student-Newman-Keuls' post hoc analysis, $p<0.05$ vs HFPPV $=150$.

Increasing the RR at constant alveolar ventilation, we obtained a progressive decrease in $V_{\mathrm{T}} \mathrm{S}$ reaching levels below $4 \mathrm{~mL} / \mathrm{kg}$. This finding challenges the paradigm - promulgated by the design of many clinical trials that RRs should be kept equal to or less than 35 breaths per minute [5,26-28]. In our model of severe ARDS, the standard of care [5] settings of $V_{\mathrm{T}} \mathrm{S}$ at $6 \mathrm{~mL} / \mathrm{kg}$ and a maximum $\mathrm{RR}$ of 35 breaths $/ \mathrm{min}$ led to a median $\mathrm{PaCO}_{2}$ value of $81 \mathrm{mmHg}$ with a median $\mathrm{pH}$ of 7.13. Targeting a $\mathrm{PaCO}_{2}$ of $60 \mathrm{mmHg}$, we were able to reduce $V_{\mathrm{T}}$ by $36 \%$ with a RR of 150 breaths per minute. Other authors have shown, in an experimental model of ARDS, that higher RRs allow for a reduction in $V_{\mathrm{T}}$ when associated with a strategy to lower the dead space (aspiration of dead space) [29,30]. Similarly, a recent study in patients with ARDS showed that protective $V_{\mathrm{T}}$ around $4 \mathrm{~mL} / \mathrm{kg}$ can be achieved with modest increments in RR, provided that care is taken to minimize the circuit dead space [31]. These studies combined increases in RR with other measures to decrease the dead space. Our findings on the isolated effect of RR on the reduction of tidal volume help understand the independent effect of manipulating the RR. 


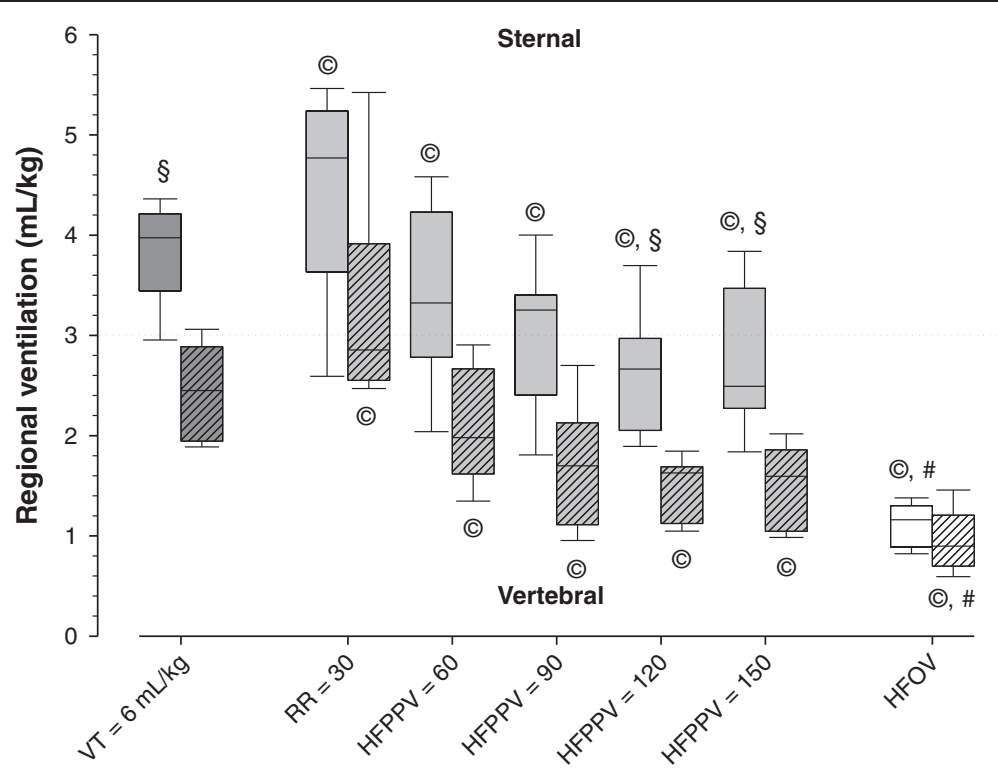

Figure 3 Regional ventilation $(\mathrm{mL} / \mathrm{kg})$ in the sternal and vertebral portions of the thorax measured through EIT. ${ }^{\ominus}$ Student-Newman-Keuls' post hoc analysis, $p<0.05$ vs stabilization step $\left(V_{T}=6 \mathrm{~mL} / \mathrm{kg}\right.$ and $\mathrm{RR}=35$ breaths/min) (Friedman's test, $p<0.001$ ); \#Student-Newman-Keuls' post hoc analysis, $p<0.05$ vs HFPPV $=150$ (Friedman's test, $p<0.001$ ); ${ }^{5}$ Wilcoxon's test, $p<0.007$ (Bonferroni's correction for multiple comparisons) vs the vertebral region (gravitational-dependent region).

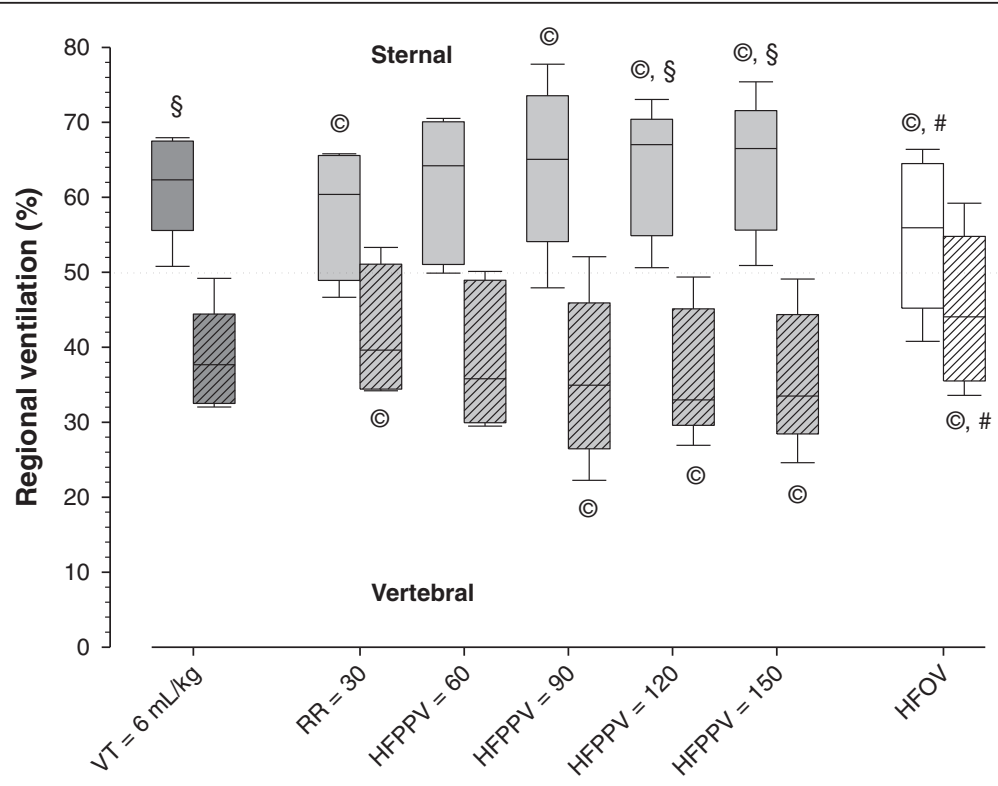

Figure 4 Distribution of regional ventilation (\%) in the sternal and vertebral portions of the thorax measured through EIT. ${ }^{\circ}$ Student-Newman-Keuls' post hoc analysis, $p<0.05$ vs stabilization step $\left(V_{T}=6 \mathrm{~mL} / \mathrm{kg}\right.$ and $\mathrm{RR}=35$ breaths/min) (Friedman's test, $\left.p<0.001\right)$; "Student-Newman-Keuls' post hoc analysis, $p<0.05$ vs HFPPV $=150$ (Friedman's test, $p<0.001$ ); ${ }^{\S}$ Wilcoxon's test, $p<0.007$ (Bonferroni's correction for multiple comparisons) vs the vertebral region (gravitational-dependent region). 
Table 3 Hemodynamic and metabolic variables during the ventilatory modes studied

\begin{tabular}{|c|c|c|c|c|c|c|c|c|}
\hline Variable & $\begin{array}{c}V_{\mathrm{T}}= \\
6 \mathrm{~mL} / \mathrm{kg}\end{array}$ & $\begin{array}{c}\mathrm{RR}= \\
30\end{array}$ & $\begin{array}{c}\text { HFPPV }= \\
60\end{array}$ & $\begin{array}{c}\text { HFPPV }= \\
90\end{array}$ & $\begin{array}{c}\text { HFPPV }= \\
120\end{array}$ & $\begin{array}{c}\text { HFPPV }= \\
150\end{array}$ & HFOV & $\begin{array}{c}p \\
\text { value }^{\mathrm{a}}\end{array}$ \\
\hline \multicolumn{9}{|l|}{ Hemodynamic } \\
\hline $\begin{array}{l}\text { Heart rate } \\
(\mathrm{bpm})\end{array}$ & $\begin{array}{c}144 \\
{[125,165]}\end{array}$ & $\begin{array}{c}165 \\
{[124,182]}\end{array}$ & $\begin{array}{c}173 \\
{[144,181]}\end{array}$ & $\begin{array}{c}169 \\
{[130,189]}\end{array}$ & $\begin{array}{c}164 \\
{[128,196]}\end{array}$ & $\begin{array}{c}173 \\
{[142,196]}\end{array}$ & $\begin{array}{c}145 \\
{[122,155]}\end{array}$ & $\begin{array}{l}P= \\
0.210\end{array}$ \\
\hline $\begin{array}{l}\text { Cardiac index } \\
(\mathrm{mL} / \mathrm{kg} / \mathrm{min})\end{array}$ & $\begin{array}{c}138 \\
{[128,153]}\end{array}$ & $\begin{array}{c}126 \\
{[121,145]}\end{array}$ & $\begin{array}{c}145 \\
{[120,169]}\end{array}$ & $\begin{array}{c}127 \\
{[115,158]}\end{array}$ & $\begin{array}{c}141 \\
{[118,166]}\end{array}$ & $\begin{array}{c}132 \\
{[116,168]}\end{array}$ & $\begin{array}{c}126 \\
{[101,142]}\end{array}$ & $\begin{array}{c}P= \\
0.363\end{array}$ \\
\hline $\begin{array}{l}\text { SV } \\
(\mathrm{mL})\end{array}$ & $\begin{array}{c}28 \\
{[26,42]}\end{array}$ & $\begin{array}{c}27 \\
{[24,41]}\end{array}$ & $\begin{array}{c}27 \\
{[26,35]}\end{array}$ & $\begin{array}{c}26 \\
{[23,44]}\end{array}$ & $\begin{array}{c}27 \\
{[26,34]}\end{array}$ & $\begin{array}{c}30 \\
{[26,35]}\end{array}$ & $\begin{array}{c}31 \\
{[22,44]}\end{array}$ & $\begin{array}{c}P= \\
0.916\end{array}$ \\
\hline $\begin{array}{l}\mathrm{ABPm} \\
(\mathrm{mmHg})\end{array}$ & $\begin{array}{c}90 \\
{[75,107]}\end{array}$ & $\begin{array}{c}86 \\
{[75,112]}\end{array}$ & $\begin{array}{c}84 \\
{[72,97]}\end{array}$ & $\begin{array}{c}91 \\
{[77,100]}\end{array}$ & $\begin{array}{c}83 \\
{[70,112]}\end{array}$ & $\begin{array}{c}78 \\
{[69,105]}\end{array}$ & $\begin{array}{c}82 \\
{[72,98]}\end{array}$ & $\begin{array}{c}P= \\
0.320\end{array}$ \\
\hline $\begin{array}{l}\text { PAPm } \\
(\mathrm{mmHg})\end{array}$ & $\begin{array}{c}43 \\
{[38,52]}\end{array}$ & $\begin{array}{c}34 \\
{[31,37]^{b}}\end{array}$ & $\begin{array}{c}34 \\
{[28,36]^{\mathrm{b}}}\end{array}$ & $\begin{array}{c}36 \\
{[33,37]^{b}}\end{array}$ & $\begin{array}{c}33 \\
{[30,47]^{b}}\end{array}$ & $\begin{array}{c}38 \\
{[30,43]^{\mathrm{b}}}\end{array}$ & $\begin{array}{c}31 \\
{[30,40]^{\mathrm{b}}}\end{array}$ & $\begin{array}{l}P= \\
0.018\end{array}$ \\
\hline $\begin{array}{l}\text { CVP } \\
(\mathrm{mmHg})\end{array}$ & $\begin{array}{c}9 \\
{[9,12]}\end{array}$ & $\begin{array}{c}8 \\
{[7,12]}\end{array}$ & $\begin{array}{c}8 \\
{[6,10]}\end{array}$ & $\begin{array}{c}9 \\
{[6,10]}\end{array}$ & $\begin{array}{c}8 \\
{[7,10]}\end{array}$ & $\begin{array}{c}9 \\
{[7,10]}\end{array}$ & $\begin{array}{c}11 \\
{[10,12]^{c}}\end{array}$ & $\begin{array}{c}P= \\
0.017\end{array}$ \\
\hline $\begin{array}{l}\text { PAOP } \\
(\mathrm{mmHg})\end{array}$ & $\begin{array}{c}12 \\
{[11,15]}\end{array}$ & $\begin{array}{c}12 \\
{[11,15]}\end{array}$ & $\begin{array}{c}12 \\
{[9,14]}\end{array}$ & $\begin{array}{c}12 \\
{[10,14]}\end{array}$ & $\begin{array}{c}12 \\
{[10,15]}\end{array}$ & $\begin{array}{c}12 \\
{[10,15]}\end{array}$ & $\begin{array}{c}14 \\
{[12,17]}\end{array}$ & $\begin{array}{c}P= \\
0.042\end{array}$ \\
\hline $\begin{array}{l}\mathrm{SvO}_{2} \\
(\mathrm{mmHg})\end{array}$ & $\begin{array}{c}54 \\
{[47,70]}\end{array}$ & $\begin{array}{c}70 \\
{[49,79]}\end{array}$ & $\begin{array}{c}68 \\
{[48,71]}\end{array}$ & $\begin{array}{c}63 \\
{[48,66]}\end{array}$ & $\begin{array}{c}64 \\
{[43,74]}\end{array}$ & $\begin{array}{c}65 \\
{[55,73]}\end{array}$ & $\begin{array}{c}65 \\
{[50,75]}\end{array}$ & $\begin{array}{l}P= \\
0.140\end{array}$ \\
\hline $\begin{array}{l}\text { SVRI (dynes.s }{ }^{-1} \\
\left(\mathrm{~cm}^{5}\right)^{-1} \cdot \mathrm{kg}^{-1}\end{array}$ & $\begin{array}{c}51.8 \\
{[41.8,56.4]}\end{array}$ & $\begin{array}{c}47.1 \\
{[39.8,65.6]}\end{array}$ & $\begin{array}{c}47.0 \\
{[35.0,50.9]}\end{array}$ & $\begin{array}{c}52.7 \\
{[36.7,61.4]}\end{array}$ & $\begin{array}{c}41.7 \\
{[33.4,63.6]}\end{array}$ & $\begin{array}{c}42.4 \\
{[28.8,66.5]}\end{array}$ & $\begin{array}{c}50.4 \\
{[31.6,55.8]}\end{array}$ & $\begin{array}{l}P= \\
0.558\end{array}$ \\
\hline $\begin{array}{l}\text { PVRI (dynes. } \mathrm{s}^{-1} \text {. } \\
\left(\mathrm{cm}^{5}\right)^{-1} \cdot \mathrm{kg}^{-1}\end{array}$ & $\begin{array}{c}22.3 \\
{[17.5,25.7]}\end{array}$ & $\begin{array}{c}15.7 \\
{[13.0,16.8]}\end{array}$ & $\begin{array}{c}15.6 \\
{[10.9,17.7]}\end{array}$ & $\begin{array}{c}16.7 \\
{[13.9,17.7]}\end{array}$ & $\begin{array}{c}14.2 \\
{[12.4,20.8]}\end{array}$ & $\begin{array}{c}16.8 \\
{[12.0,20.7]}\end{array}$ & $\begin{array}{c}13.6 \\
{[10.9,18.2]}\end{array}$ & $\begin{array}{l}P= \\
0.133\end{array}$ \\
\hline \multicolumn{9}{|l|}{ Metabolic } \\
\hline $\begin{array}{l}\text { Lactate } \\
(\mathrm{mEq} / \mathrm{L})\end{array}$ & $\begin{array}{c}1.7 \\
{[1.1,2.1]}\end{array}$ & $\begin{array}{c}1.3 \\
{[0.8,1.7]}\end{array}$ & $\begin{array}{c}1.6 \\
{[0.8,2.0]}\end{array}$ & $\begin{array}{c}1.7 \\
{[1.1,2.0]}\end{array}$ & $\begin{array}{c}1.4 \\
{[1.0,1.9]}\end{array}$ & $\begin{array}{c}1.6 \\
{[0.9,2.3]}\end{array}$ & $\begin{array}{c}1.5 \\
{[1.1,1.8]}\end{array}$ & $\begin{array}{c}P= \\
0.762\end{array}$ \\
\hline $\mathrm{pH}$ & $\begin{array}{c}7.13 \\
{[7.08,7.2]}\end{array}$ & $\begin{array}{c}7.25 \\
{[7.24,7.33]^{b}}\end{array}$ & $\begin{array}{c}7.25 \\
{[7.24,7.35]^{\mathrm{b}}}\end{array}$ & $\begin{array}{c}7.26 \\
{[7.23,7.33]^{b}}\end{array}$ & $\begin{array}{c}7.27 \\
{[7.2,7.3]^{\mathrm{b}}}\end{array}$ & $\begin{array}{c}7.26 \\
{[7.21,7.34]^{\mathrm{b}}}\end{array}$ & $\begin{array}{c}7.25 \\
{[7.2,7.32]^{b}}\end{array}$ & $\begin{array}{c}P= \\
0.002\end{array}$ \\
\hline $\begin{array}{l}\text { Temperature } \\
\left({ }^{\circ} \mathrm{C}\right)\end{array}$ & $\begin{array}{c}38.6 \\
{[37.3,39.2]}\end{array}$ & $\begin{array}{c}39.7 \\
{[38.0,39.8]^{\mathrm{b}}}\end{array}$ & $\begin{array}{c}39.4 \\
{[37.6,39.6]^{b}}\end{array}$ & $\begin{array}{c}39.2 \\
{[38.1,39.6]^{\mathrm{b}}}\end{array}$ & $\begin{array}{c}38.8 \\
{[37.6,39.6]^{\mathrm{b}}}\end{array}$ & $\begin{array}{c}39.0 \\
{[37.8,39.5]^{\mathrm{b}}}\end{array}$ & $\begin{array}{c}39.2 \\
{[38.1,39.8]^{b}}\end{array}$ & $\begin{array}{c}P= \\
0.007\end{array}$ \\
\hline $\begin{array}{l}\text { Fluid balance } \\
(\mathrm{mL})\end{array}$ & $\begin{array}{c}-50 \\
{[-242,-5]}\end{array}$ & $\begin{array}{c}170 \\
{[101,278]}\end{array}$ & $\begin{array}{c}40 \\
{[-22,102]}\end{array}$ & $\begin{array}{c}100 \\
{[67,110]}\end{array}$ & $\begin{array}{c}60 \\
{[5,108]}\end{array}$ & $\begin{array}{c}40 \\
{[-58,88]}\end{array}$ & $\begin{array}{c}30 \\
{[-21,50]}\end{array}$ & $\begin{array}{c}P= \\
0.044\end{array}$ \\
\hline
\end{tabular}

Values are presented as median [P25th,P75th]. ${ }^{a}$ The $p$ value was obtained through Friedman's test; ${ }^{\text {b}}$ Student-Newman-Keuls'

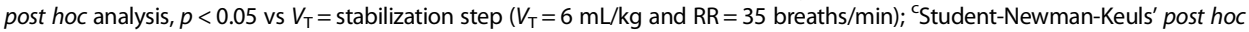
analysis, $p<0.05$ vs HFPPV $=150$.

The increases in RR were not associated with significant changes in gas exchange. We did notice a not significant but progressive fall in the median $\mathrm{PaO}_{2} / \mathrm{FiO}_{2}(\mathrm{P} / \mathrm{F})$ ratio with increases in RR above 30 breaths per minute amounting to a fall of $26 \%$ at a RR of 150 breaths per minute (Table 2). Concurrently, the $T_{\text {insp }} / T_{\text {tot }}$ ratio increased from $19 \%$ to $42 \%$ when RR increased from 30 to 150 (Table 2), due to the fixed inspiratory flow rate and the need for higher minute ventilation at high $R R$. These increases in the $T_{\text {insp }} / T_{\text {tot }}$ ratio would favor a change in the $\mathrm{P} / \mathrm{F}$ ratio in the opposite direction of the trend we found. These observations emphasize that with our relatively small sample size, we might have been underpowered to detect some differences such as the P/F ratio variation. If such trend proved significant in a larger study, it is possible that the lower tidal volumes at higher RR have favored the development of absorption atelectasis, although we cannot exclude that hemodynamic factors may played a role.

HFOV, a more classical strategy than HFPPV to provide adequate gas exchange at very low $V_{\mathrm{T}} \mathrm{s}[32,33]$, has been recently shown to provide no benefit or even cause harm to patients with ARDS $[16,17]$. Our results showed that HFOV $=5 \mathrm{~Hz}$ could stabilize the $\mathrm{PaCO}_{2}$ with $V_{\mathrm{T}} \mathrm{S} 26 \%$ lower than HFPPV $=150$, however, with a RR twice as high 
and a $P_{\text {mean }} 30 \%$ higher [15]. This is illustrative of the disproportionate increases in RR to maintain alveolar ventilation at progressively lower $V_{\mathrm{T}} \mathrm{S}$, especially when close to the dead space, and the need to increase $P_{\text {mean }}$, which may have deleterious hemodynamic effects. The consequence of this ventilation inefficiency might be an increased dissipation of energy in the lungs, potentially leading to more lung injury even at reduced stress and strain per breath. Therefore, reducing $V_{\mathrm{T}}$ without increasing mean airway pressure might be of special interest. In that sense, HFPPV might offer a better compromise between $V_{\mathrm{T}}$ and RR than HFOV.

Ventilation decreased more in the gravitation-dependent regions, a finding suggestive of reabsorption atelectasis, air trapping, or incomplete filling of those regions due to airway narrowing. Even after taking this 'functional baby lung' into account, the net result was likely a lesser degree of tidal lung stretch as suggested by the decrease in driving pressures and plateau pressures. Additionally, despite a preferential reduction in dependent ventilation (Figure 4), HFPPV could result in lower regional $V_{\mathrm{T}}$ in nondependent regions (Figure 3).

\section{Limitations}

Our study has several limitations. First, the arbitrary choice of the target $\mathrm{CO}_{2}$ level during HFPPV can be criticized. The $\mathrm{CO}_{2}$ value can be a confounding factor of the ventilatory settings during ARDS ventilation, with some studies showing a protective [34,35] and others a potentially deleterious role [36,37]. We chose a narrow range of 57 to $63 \mathrm{mmHg}$ to avoid such potential confounding effect and to avoid significant acidosis $(\mathrm{pH}<7.15)$, a goal we achieved in all experimental conditions. Likely, the main findings of the study would maintain had a normocapnia target been applied. Second, our study design, with sequential changes in the ventilator settings, was susceptible to carryover phenomena. We tried to avoid that effect through the randomization of sequences, the disconnection from the ventilator between the steps, and through a prolonged wait to the $\mathrm{PaCO}_{2}$ equilibrium. Third, the performance of conventional ventilators declines at very high RRs and low $V_{\mathrm{T}} \mathrm{s}$, especially if low-compliance tubing is not employed [38]. Fourth, we did not rule out that histological damage to the lungs might have happened at those very high RRs. Fifth, HFOV was the last step of the study due to logistic issues and at this time the animals had significant positive fluid balances. This could be one explanation why HFOV was not associated with hemodynamic alterations, even with the use of higher $P_{\text {mean }}$. Finally, we cannot directly extrapolate these experimental findings to patients, who have longer time constants than pigs and might not tolerate RRs as high. Interestingly, those with the most severe lung injury tolerate better very high $R R$, because of their low time constants. Even so, in our experience, it is difficult to apply RR $>60$ breaths per minute to patients without leading to intrinsic PEEP.

\section{Conclusions}

In an animal model of severe ARDS, as compared to the standard protective ventilation, high-frequency positive-pressure ventilation delivered by a conventional ventilator allowed further reductions in tidal volume and in inspiratory pressures. As such, HFPPV could be a well-suited alternative in the treatment of severe ARDS with very low lung compliance, although its impact on lung inflammation still awaits evaluation. 


\begin{abstract}
Abbreviations
ABPm: mean systemic arterial blood pressure; ARDS: acute respiratory distress syndrome; $\mathrm{CCO}_{2}$ : pulmonary capillary oxygen content; $C_{\text {dyn }}$ : dynamic compliance; $\mathrm{Cl}$ : cardiac index; $C_{\text {static }}$ : static compliance; $C$ PP: central venous pressure; $\mathrm{CXO}_{2}$ : blood oxygen content; EIT: electrical impedance tomography; $\mathrm{EtCO}_{2}$ : airway end-tidal pressure of carbon dioxide; $\mathrm{FiO}_{2}$ : inspiratory fraction of oxygen; HFOV: high-frequency oscillatory ventilation; HFPPV: high-frequency positivepressure ventilation; I/E: inspiratory/expiratory time ratio; $\mathrm{PaCO}_{2}$ : partial arterial carbon dioxide pressure; $\mathrm{PaO}_{2}$ : partial pressure of arterial oxygen; PAOP: pulmonary artery occlusion pressure; PAPm: mean pulmonary artery pressure; PEEP: positive end-expiratory pressure; PEEPe: extrinsic positive end-expiratory pressure; PEEPi: intrinsic positive endexpiratory pressure; $P_{\text {mean }}$ : mean airway pressure; $P_{\text {peak }}$ : airway peak pressure; $P_{\text {plateau }}$ : airway plateau pressure; RR: respiratory rate; $\mathrm{SVO}_{2}$ : mixed venous blood gases; $T_{\text {insp: }}$ inspiratory time; $V_{\mathrm{T}}$ : tidal volumes.
\end{abstract}

\title{
Competing interests
}

The authors declare that they have no competing interests.

\section{Authors' contributions}

RLC designed the study, participated in the research protocols, analyzed and interpreted the data, and drafted the manuscript. MP designed the study, participated in the research protocols, helped interpret the data, and drafted the manuscript. ELVC helped design the study, participated in the research protocols, analyzed and interpreted the data, and helped draft the manuscript design. SG participated in the research protocols and analyzed the data. LB participated in the discussion, helped interpret the data, and drafted the manuscript. MBPA designed the study, analyzed and interpreted the data, and reviewed the manuscript. LCPA designed and conceived the study, participated in the research protocols, and reviewed the manuscript. All authors read and approved the final manuscript.

\section{Acknowledgements}

The authors are grateful to the Research and Education Institute, Hospital Sírio-Libanês, São Paulo, Brazil; Fundação de Amparo à Pesquisa do Estado de São Paulo (FAPESP), São Paulo, Brazil; and Financiadora de Estudos e Projetos (FINEP), Brazil, for the grant offered to the study development. We gratefully thank Marcelo do Amaral Beraldo, Mauro Roberto Tucci, Roberta Ribeiro de Santis Santiago, and Takeshi Yoshida, whose contribution to the animal experiments was very important.

\section{Author details}

${ }^{1}$ Research and Education Institute, Hospital Sírio-Libanês, Rua Dona Adma Jafet, 91, Bela Vista, São Paulo 01308-050, Brazil. 'Laboratório de Investigação Médica 09, Heart Institute (InCor), Hospital das Clínicas da Faculdade de Medicina da Universidade de São Paulo, Av. Rebouças, 381-Jardim Paulista, São Paulo, São Paulo 05401-000, Brazil. " ${ }^{3}$ Emergency Medicine Department, Faculdade de Medicina da Universidade de São Paulo, Rua Dona Adma Jafet, 91, Bela Vista, São Paulo 01308-050, Brazil. ${ }^{4}$ Department of Adult Intensive Care, Intensive Care Unit, Hospital Israelita Albert Einstein, Av. Albert Einstein, 627, Morumbi, São Paulo 05652-900, Brazil. ${ }^{5}$ St Michael's Hospital, Toronto, University of Toronto, 30 Bond Street, Toronto, Ontario M5B 1W8, Canada. ${ }^{6}$ ntensive Care Unit, Hospital Alemão Oswaldo Cruz, Rua João Julião, 331, Bela Vista, São Paulo 01323-903, Brazil.

\section{Received: 18 November 2013 Accepted: 21 March 2014}

Published: 9 May 2014

\section{References}

1. Rubenfeld GD, Caldwell E, Peabody E, Weaver J, Martin DP, Neff M, Stern EJ, Hudson LD (2005) Incidence and outcomes of acute lung injury. N Engl J Med 353(16):1685-1693

2. Webb HH, Tierney DF (1974) Experimental pulmonary edema due to intermittent positive pressure ventilation with high inflation pressures. Protection by positive end-expiratory pressure. Am Rev Respir Dis 110(5):556-565

3. Ranieri VM, Giunta F, Suter PM, Slutsky AS (2000) Mechanical ventilation as a mediator of multisystem organ failure in acute respiratory distress syndrome. JAMA 284(1):43-44

4. Amato MB, Barbas CS, Medeiros DM, Magaldi RB, Schettino GP, Lorenzi-Filho G, Kairalla RA, Deheinzelin D, Munoz C, Oliveira R, Takagaki TY, Carvalho CR (1998) Effect of a protective-ventilation strategy on mortality in the acute respiratory distress syndrome. N Engl J Med 338(6):347-354

5. (2000) Ventilation with lower tidal volumes as compared with traditional tidal volumes for acute lung injury and the acute respiratory distress syndrome. The Acute Respiratory Distress Syndrome Network. N Engl J Med 342(18):1301-1308

6. Fuchs H, Mendler MR, Scharnbeck D, Ebsen M, Hummler HD (2011) Very low tidal volume ventilation with associated hypercapnia - effects on lung injury in a model for acute respiratory distress syndrome. PLoS One 6(8):e23816

7. Mekontso Dessap A, Charron C, Devaquet J, Aboab J, Jardin F, Brochard L, Vieillard-Baron A (2009) Impact of acute hypercapnia and augmented positive end-expiratory pressure on right ventricle function in severe acute respiratory distress syndrome. Intensive Care Med 35(11):1850-1858

8. Otulakowski G, Kavanagh BP (2011) Hypercapnia in acute illness: sometimes good, sometimes not. Crit Care Med 39(6):1581-1582

9. Hager DN, Fessler HE, Kaczka DW, Shanholtz CB, Fuld MK, Simon BA, Brower RG (2007) Tidal volume delivery during high-frequency oscillatory ventilation in adults with acute respiratory distress syndrome. Crit Care Med 35 (6):1522-1529

10. Eriksson I, Sjostrand U (1980) Effects of high-frequency positive-pressure ventilation (HFPPV) and general anesthesia on intrapulmonary gas distribution in patients undergoing diagnostic bronchoscopy. Anesth Analg 59(8):585-593

11. Barzilay E, Lev A, Ibrahim M, Lesmes C (1987) Traumatic respiratory insufficiency: comparison of conventional mechanical ventilation to high-frequency positive pressure with low-rate ventilation. Crit Care Med 15(2):118-121

12. Barzilay E, Lev A, Lesmes C, Fleck R, Khourieh A (1984) Combined use of HFPPV with low-rate ventilation in traumatic respiratory insufficiency. Intensive Care Med 10(4):197-200 
13. Abu-Dbai J, Flatau E, Lev A, Kohn D, Monis-Hass I, Barzilay E (1983) The use of conventional ventilators for high frequency positive pressure ventilation. Crit Care Med 11(5):356-358

14. Iguchi N, Hirao O, Uchiyama A, Mashimo T, Nishimura M, Fujino Y (2010) Evaluation of performance of two high-frequency oscillatory ventilators using a model lung with a position sensor. J Anesth 24(6):888-892

15. Guervilly C, Forel JM, Hraiech S, Demory D, Allardet-Servent J, Adda M, Barreau-Baumstark K, Castanier M, Papazian L, Roch A (2012) Right ventricular function during high-frequency oscillatory ventilation in adults with acute respiratory distress syndrome. Crit Care Med 40(5):1539-1545

16. Young D, Lamb SE, Shah S, MacKenzie I, Tunnicliffe W, Lall R, Rowan K, Cuthbertson BH (2013) High-frequency oscillation for acute respiratory distress syndrome. N Engl J Med 368(9):806-813

17. Ferguson ND, Cook DJ, Guyatt GH, Mehta S, Hand L, Austin P, Zhou Q, Matte A, Walter SD, Lamontagne F, Granton JT, Arabi YM, Arroliga AC, Stewart TE, Slutsky AS, Meade MO (2013) High-frequency oscillation in early acute respiratory distress syndrome. N Engl I Med 368(9):795-805

18. Sjostrand UH, Eriksson IA (1980) High rates and low volumes in mechanical ventilation-not just a matter of ventilatory frequency. Anesth Analg 59(8):567-576

19. Wattwil LM, Sjostrand UH, Borg UR (1983) ) Comparative studies of IPPV and HFPPV with PEEP in critical care patients. I: a clinical evaluation. Crit Care Med 11(1):30-37

20. Costa EL, Chaves CN, Gomes S, Beraldo MA, Volpe MS, Tucci MR, Schettino IA, Bohm SH, Carvalho CR, Tanaka H, Lima RG, Amato MB (2008) Real-time detection of pneumothorax using electrical impedance tomography. Crit Care Med 36(4):1230-1238

21. Victorino JA, Borges JB, Okamoto VN, Matos GF, Tucci MR, Caramez MP, Tanaka H, Sipmann FS, Santos DC, Barbas CS, Carvalho CR, Amato MB (2004) Imbalances in regional lung ventilation: a validation study on electrical impedance tomography. Am J Respir Crit Care Med 169(7):791-800

22. Gomes S, Belmino R, Hirota A, Costa ELC, Barbeiro DF, Tucci MR, Gregores GB, Beraldo MA, Timenetsky K, Borges JB, Carvalho CRR, Amato MBP (2009) A New Experimental Model of Acute Lung injury. Am J Respir Crit Care Med 179:A3568

23. Imai Y, Parodo J, Kajikawa O, de Perrot M, Fischer S, Edwards V, Cutz E, Liu M, Keshavjee S, Martin TR, Marshall JC, Ranieri VM, Slutsky AS (2003) Injurious mechanical ventilation and end-organ epithelial cell apoptosis and organ dysfunction in an experimental model of acute respiratory distress syndrome. JAMA 289(16):2104-2112

24. Terragni PP, Del Sorbo L, Mascia L, Urbino R, Martin EL, Birocco A, Faggiano C, Quintel M, Gattinoni L, Ranieri VM (2009) Tidal volume lower than $6 \mathrm{ml} / \mathrm{kg}$ enhances lung protection: role of extracorporeal carbon dioxide removal. Anesthesiology 111(4):826-835

25. Terragni PP, Rosboch G, Tealdi A, Corno E, Menaldo E, Davini O, Gandini G, Herrmann P, Mascia L, Quintel M, Slutsky AS, Gattinoni L, Ranieri VM (2007) Tidal hyperinflation during low tidal volume ventilation in acute respiratory distress syndrome. Am J Respir Crit Care Med 175(2):160-166

26. Meade MO, Cook DJ, Guyatt GH, Slutsky AS, Arabi YM, Cooper DJ, Davies AR, Hand LE, Zhou Q, Thabane L, Austin P, Lapinsky S, Baxter A, Russell J, Skrobik Y, Ronco JJ, Stewart TE (2008) Ventilation strategy using low tidal volumes, recruitment maneuvers, and high positive end-expiratory pressure for acute lung injury and acute respiratory distress syndrome: a randomized controlled trial. JAMA 299(6):637-645

27. Brower RG, Lanken PN, Maclntyre N, Matthay MA, Morris A, Ancukiewizz M, Schoenfeld D, Thompson BT (2004) Higher versus lower positive end-expiratory pressures in patients with the acute respiratory distress syndrome. N Engl J Med 351(4):327-336

28. Mercat A, Richard JC, Vielle B, Jaber S, Osman D, Diehl JL, Lefrant JY, Prat G, Richecoeur J, Nieszkowska A, Gervais C, Baudot J, Bouadma L, Brochard L (2008) Positive end-expiratory pressure setting in adults with acute lung injury and acute respiratory distress syndrome: a randomized controlled trial. JAMA 299(6):646-655

29. Uttman L, Ogren H, Niklason L, Drefeldt B, Jonson B (2007) Computer simulation allows goal-oriented mechanical ventilation in acute respiratory distress syndrome. Crit Care 11(2):R36

30. Uttman L, Bitzen U, De Robertis E, Enoksson J, Johansson L, Jonson B (2012) Protective ventilation in experimental acute respiratory distress syndrome after ventilator-induced lung injury: a randomized controlled trial. $\mathrm{Br} J$ Anaesth 109(4):584-594

31. Retamal J, Libuy J, Jimenez M, Delgado M, Besa C, Bugedo G, Bruhn A (2013) Preliminary study of ventilation with $4 \mathrm{ml} / \mathrm{kg}$ tidal volume in acute respiratory distress syndrome: feasibility and effects on cyclic recruitment - derecruitment and hyperinflation. Crit Care 17(1):R16

32. Derdak S, Mehta S, Stewart TE, Smith T, Rogers M, Buchman TG, Carlin B, Lowson S, Granton J (2002) High-frequency oscillatory ventilation for acute respiratory distress syndrome in adults: a randomized, controlled trial. Am J Respir Crit Care Med 166(6):801-808

33. Sud S, Sud M, Friedrich JO, Meade MO, Ferguson ND, Wunsch H, Adhikari NK (2010) High frequency oscillation in patients with acute lung injury and acute respiratory distress syndrome (ARDS): systematic review and meta-analysis. BMJ 340:c2327

34. Laffey JG, Tanaka M, Engelberts D, Luo X, Yuan S, Tanswell AK, Post M, Lindsay T, Kavanagh BP (2000) Therapeutic hypercapnia reduces pulmonary and systemic injury following in vivo lung reperfusion. Am J Respir Crit Care Med 162 (6):2287-2294

35. Nichol AD, O'Cronin DF, Howell K, Naughton F, O'Brien S, Boylan J, O'Connor C, OToole D, Laffey JG, McLoughlin P (2009) Infection-induced lung injury is worsened after renal buffering of hypercapnic acidosis. Crit Care Med 37(11):2953-2961

36. Gates KL, Howell HA, Nair A, Vohwinkel CU, Welch LC, Beitel GJ, Hauser AR, Sznajder JI, Sporn PH (2013) Hypercapnia impairs lung neutrophil function and increases mortality in murine pseudomonas pneumonia. Am J Respir Cell Mol Biol 49(5):821-828

37. Doerr CH, Gajic O, Berrios JC, Caples S, Abdel M, Lymp JF, Hubmayr RD (2005) Hypercapnic acidosis impairs plasma membrane wound resealing in ventilator-injured lungs. Am J Respir Crit Care Med 171(12):1371-1377

38. Lyazidi A, Thille AW, Carteaux G, Galia F, Brochard L, Richard JC (2010) Bench test evaluation of volume delivered by modern ICU ventilators during volume-controlled ventilation. Intensive Care Med 36(12):2074-2080

doi:10.1186/2197-425X-2-13

Cite this article as: Cordioli et al: Moderately high frequency ventilation with a conventional ventilator allows reduction of tidal volume without increasing mean airway pressure. Intensive Care Medicine Experimental 2014 2:13. 